\title{
Securing Turkey through western-oriented foreign policy
}

Article in New perspectives on Turkey · January 2003

DOI: $10.1017 /$ S0896634600005239

\section{CITATIONS}

20

1 author:

Pinar Bilgin

Bilkent University

69 PUBLICATIONS 791 CITATIONS

SEE PROFILE
READS

59

Some of the authors of this publication are also working on these related projects: 


\title{
Securing Turkey through \\ western-oriented foreign policy
}

\section{Pınar Bilgin}

\begin{abstract}
How are Turkey's insecurities relevant to the analysis of its international relations? While it is interesting to look at how particular security concerns have affected Turkey's foreign policies at various moments in history, this article will take a different route. Following the distinction that David Campbell has drawn between "Foreign Policy" (through which others are rendered "foreign) and "foreign policy" (through which relations with others are managed), the article will explore how Turkey's insecurities have shaped a Foreign Policy that rests on the West/non-West divide. While the literature has analyzed specific acts of foreign policy and how they were crafted in response to specific military insecurities, the role that Turkey's non-military and non-specific insecurities have played in shaping its international relations has remained understudied. Thus, the literature has not been able to fully account for the centrality of Turkey's western orientation to its security. The argument here proceeds in three steps: First, the article draws attention to the necessity of looking at non-material as well as material insecurities in designing research on foreign policy. Second, it illustrates this necessity by focusing on the case of Turkey's foreign policy. Thirdly, in view of this second point the article highlights the centrality of Turkey's western orientation (i.e., its Foreign Policy) to its security, more persuasively than studies that exclusively focus on the material aspects of security.
\end{abstract}

Keywords: Turkey, security, foreign policy, critical theory, identity

Pınar Bilgin, Department of International Relations, Bilkent University, 06800, Ankara, pbilgin@bilkent.edu.tr. 


\section{Introduction}

How are Turkey's insecurities relevant to the analysis of its international relations? While it is interesting to look at how particular security concerns have affected Turkey's foreign policy practices at various moments in its history, this article will take a different route. Following the distinction that David Campbell has drawn between "Foreign Policy" (through which others are rendered "foreign") and "foreign policy" (through which relations with others who are rendered "foreign" are managed), ${ }^{1}$ this article will explore how Turkey's insecurities have shaped a "Foreign Policy" that rests on the West/non-West divide. ${ }^{2}$

At a time when Turkey's western orientation in general and relations with the European Union $(\mathrm{EU})^{3}$ in particular are questioned at home and abroad, ${ }^{4}$ it is especially important to explore the insecurities that have shaped its international relations. While the literature analyzes

1 David Campbell, Writing Security: United States Foreign Policy and the Politics of Identity (Manchester: Manchester University Press, 1992).

2 Throughout the text, I will use the following two dichotomies interchangeably: civilized/ less-thancivilized and West/non-West. Even though I acknowledge the differences between the two and do not want to essentialize them, it is pertinent to underscore how during the nineteenth and early twentieth century civilization corresponded to the West in the minds of prominent European intellectuals and policy-makers. At the time, the term "West" was also used in opposition to the East. However, as distinct from to the Cold War period when East and West were differentiated in terms of their economic organization and ideological outlook, during this period the distinction was one of status vis-à-vis civilization. Ottoman self-understanding at the time could perhaps best be described as between two worlds. While the Ottomans continued to represent themselves as civilized, at the same time they bought into the notion of civilization as propounded by their European counterparts and sought to prove their civilized status vis-à-vis the European/International Society. See, Selim Deringil, “They Live in a State of Nomadism and Savagery': The Late Ottoman Empire and the Post-Colonial Debate," Comparative Studies in Society and History 45, no. 2 (2003).

3 Notwithstanding the significant advances made in Turkey's relations with the EU since the latter's 1999 decision to recognize Turkey's candidacy and the 2005 decision to begin membership negotiations, relations remain strained. See, Gülnur Aybet, "Turkey and the EU after the First Year of Negotiations: Reconciling Internal and External Policy Challenges," Security Dialogue 37, no. 4 (2006).

4 The following provide different accounts on Turkey's difficult relations with the West in the post-postCold War period: see, for example, Graham E. Fuller, “Turkey's New Eastern Orientation," in Turkey's New Geopolitics: From the Balkans to Western China, ed. Graham E. Fuller and Ian O. Lesser (1993), Samuel P. Huntington, "Clash of Civilizations?," Foreign Affairs 72, no. 3 (1993), Ömer Taşpınar, "The Old Turks' Revolt," Foreign Affairs 86, no. 6 (2007), Ola Tunander, "A New Ottoman Empire? The Choice for Turkey: Euro-Asian Centre vs National Fortress," Security Dialogue 26, no. 4 (1995). There is also Ahmet Davutoğlu's best-selling book Stratejik Derinlik, in which the author has challenged not the western orientation, but the western focus of Turkey's foreign policy and called for a more multidimensional stance. See, Ahmet Davutoğlu, Stratejik Derinlik (İstanbul: Küre Yayınları, 2001). While efforts to make Turkey's foreign policy more multi-dimensional are not new, but go back as far as the 1960s, Davutoğlu has justified the need for a multi-dimensional outlook with reference to Turkey's historical and religio-cultural characteristics, which he takes as pre-given and immutable. Put differently, Davutoğlu has made a case for a change in Turkey's foreign policy stance, not on geo-political, economic, or power-political terms, but on culturalist terms. See the final section for further discussion. 
specific acts of foreign policy and how they were crafted in response to specific military insecurities, ${ }^{5}$ the role that Turkey's non-military and non-specific insecurities have played in shaping its international relations has remained understudied. ${ }^{6}$ Thus, the literature has not been able to fully account for the centrality of Turkey's western orientation (i.e., its Foreign Policy) to its security.

This article aims to accomplish three things: First, it underscores the necessity of looking at both non-material and material aspects of security in foreign policy analysis. Second, it illustrates this necessity by focusing on the case of Turkey's international relations. Thirdly, in view of the second point it highlights the centrality of Turkey's western orientation to its security, more persuasively than accounts that exclusively focus on the material aspects of security. It is argued that Turkey's search to locate itself in the West could be read partly (but not wholly, for there is more to Turkey's search for security than its western orientation, just as there is more to Turkey's western orientation than its search for security) as a response to non-military and non-specific insecurities of the early Republican era - namely, negotiating Turkey's "difference" in the face of a European/International Society that was ambivalent towards its difference. This Foreign Policy over time has allowed specific acts of western-oriented foreign policy.

\section{In/security, identity and foreign policy}

Prevalent approaches to international relations offer analyses of foreign policy that focus on specific threats encountered by states and policies devised to address them. ${ }^{7}$ This literature takes threats as a given and focuses on the process that begins once the specific issue at hand is identified as a threat to a particular country's security. This literature understands policy in a narrow sense - in terms of responding

5 For early examples, see, Metin Tamkoç, "Turkey's Quest for Security through Defensive Alliances," Milletlerarası Münasebetler Türk Yıllığı 2 (1961), Metin Tamkoç, The Warrior Diplomats: Guardians of National Security and Modernization of Turkey (Salt Lake City: University of Utah Press, 1976).

6 While there is a rich Political Science literature that examines the domestic political dynamics its insights seldom make their way into the study of Turkey's international relations; see, for example, Metin Heper, Ayşe Öncü, and Heinz Kramer, eds., Turkey and the West: Changing Political and Cultural Identities (New York: I. B. Tauris, 1993), Sibel Bozdoğan and Reşat Kasaba, eds., Rethinking Modernity and National Identity in Turkey (Seattle: University of Washington Press, 1997), Taha Parla and Andrew Davison, Corporatist Ideology in Kemalist Turkey (Syracuse: Syracuse University Press, 2004). On the apparent divide between the production of knowledge in Political Science and International Relations in Turkey, see, Boğaç Erozan and ilter Turan, "The Development of Political Science in Turkey," PS (April 2004).

7 The most prominent example of this literature is: Graham T. Allison, Essence of Decision: Explaining the Cuban Missile Crisis (Boston: Little, 1971). 
to threats, but not in terms of understanding how problems are turned into threats. ${ }^{8}$

Critical approaches to International Relations have for a long time revealed the limits of such analyses. ${ }^{9}$ David Campbell's groundbreaking Writing Security pointed to how Foreign Policy, through which states render others foreign, also sets the framework within which day-to-day relations with others are managed - that is, foreign policy. While mainstream IR has focused on the latter, Campbell has shown how focusing on the former provides deeper insight into the construction of state identity vis-à-vis others as well as of policies put into practice for shaping relations with others. ${ }^{10}$ For states do not just encounter threats. They take active part in constructing them as such; they make choices in favor of (or against) defining issues as threats. ${ }^{11}$ These choices are shaped by (and, in turn, shape) identities and interests, which have material and non-material aspects. ${ }^{12}$

The contrast between prevalent approaches to foreign policy analysis and their critics becomes clearer when one juxtaposes the insights gleaned from Graham Allison and Jutta Weldes's respective analyses of the Cuban Missile Crisis of $1962 .{ }^{13}$ Allison's take on the Cuban Missile Crisis is in itself a critique of policy analyses that rely on the rational actor model (RAM). While useful when essential data required for the analysis of policy is not easily available, RAM is problematic in so far as it leaves too much to the guesswork of the analyst. ${ }^{14}$ What is more, it may

8 From a critical perspective, the difference between threats and problems is not one of perception understood in the everyday sense of the term. Prevalent approaches to IR have incorporated the study of mis/perception into policy analysis in the 1970s; see, Robert Jervis, Perception and Misperception in International Politics (Princeton: Princeton University Press, 1976). Since then, advances in the study of perception in the field of cognitive psychology have further underscored how culture shapes perception. From a perspective that treats culture as a construct and acknowledges the role played by the politics of in/security in its construction, the process through which problems are turned into threats is the focus of analysis, as opposed to explaining this process away by invoking perception in the everyday sense of the term.

9 Mark Laffey, "Locating Identity: Performativity, Foreign Policy and State Action," Review of International Studies 26, no. 3 (2000). Also see, Valerie Hudson, Foreign Policy Analysis: Yesterday, Today and Tomorrow (Lanham: Rowman \& Littlefield, 2007).

10 Campbell, Writing Security.

11 See, Jutta Weldes, "Constructing National Interests," European Journal of International Relations 2, no. 3 (1996).

12 See, Bill McSweeney, Security, Identity and Interests: A Sociology of International Relations (Cambridge: Cambridge University Press, 1999).

13 Graham T. Allison and Philip Zelikow, Essence of Decision: Explaining the Cuban Missile Crisis (New York: Longman, 1999), Weldes, "Constructing National Interests.", Jutta Weldes, "The Cultural Production of Crises: US Identity and Missiles in Cuba," in Cultures of Insecurity: States, Communities, and the Production of Danger, ed. Jutta Weldes (Minneapolis: University of Minnesota Press, 1999).

14 Allison and Zelikow, Essence of Decision, 49. 
produce misleading results, as Allison has revealed in his meticulous archival study of the Cuban Missile Crisis. While analysts who use RAM have explained the avoidance of nuclear war in 1962 with reference to the caution imposed on actors during times of nuclear standoff, Allison has cautioned against such confidence, arguing that the dynamics of organizational behavior and bureaucratic politics factor in the making and implementation of decisions in ways that RAM cannot capture. ${ }^{15}$

Having successfully revealed the blind spots of RAM and called for integrating all three models in analyzing foreign policy, Allison left one question untouched: How did the crisis come about? In a manner typical of prevalent approaches to foreign policy analysis (of which he was otherwise critical), Allison focused only on how the crisis was managed and resolved. He was not interested in the question of how the dangerous encounter between the United States, the Soviet Union and Cuba turned into a crisis, as opposed to a mere problem to be addressed through diplomatic channels. In Campbell's terms, Allison's research focused on the conduct of US foreign policy without inquiring into US Foreign Policy. The latter is an important question to ask, because what rendered the Cuban Missile Crisis a crisis, as Jutta Weldes has argued, was not the mere presence of Soviet missiles in Cuba or the strategic threat posed by those missiles. US policy-makers found particularly threatening the challenge that those missiles posed to US identity as the "leader of the Free World." 16 Put differently, it was not only the destructive capability of the missiles (the material factor), but also the destructive political consequences of the Soviet and Cuban daring and ability to transfer and plant those missiles in the US "backyard" (the non-material factor) that constituted a threat to its security.

Indeed, a prominent member of the US administration, Secretary of Defense Robert McNamara, was also of the opinion that it was not merely material factors that constituted US insecurities. Also worrying was the non-material threat posed by the very same missiles. At the time, the United States was considered to be holding "the West" together, by virtue of the extended deterrence it provided. Failing to stand against the Soviet Union in what the United States considered its own backyard would likely have had consequences for the broader security strategy of the United States. Had the United States not constructed its identity as "the leader of the Free World," the crisis might have played out differently, or the encounter may not have turned into a crisis at all. Hence

15 Allison, Essence of Decision, Allison and Zelikow, Essence of Decision.

16 Weldes, "Constructing National Interests.", Weldes, "The Cultural Production of Crises." 
the conclusion of Weldes et al:: "insecurity, rather than being external to the object to which it presents a threat, is both implicated in and an effect of the very process of establishing and re-establishing the object's identity." 17

In juxtaposing the insights of prevalent approaches to foreign policy analysis and their critics, ${ }^{18}$ and underscoring the insights that the latter provides into the mutually constitutive relationship between in/ security and identity, my aim is not to set the material and non-material dimensions of security against each other. Rather, following critical approaches, ${ }^{19}$ I understand in/security as a whole with reference to both material and non-material dimensions.

That said, the abovementioned materialist bias of prevalent approaches to foreign policy analysis has so far resulted in relative neglect of non-material insecurities, although non-material insecurities are integral to actors' re-constitution of their identities and interests. What is more, non-material insecurities are no less real than material insecurities in terms of the anxieties that they cause or the destruction that they bring about. Consider western European insecurities in the immediate aftermath of World War II. While the military aspect of western European insecurities have been accounted for in the literature (as with the threat of Soviet expansionism and German revivalism), critical approaches have also highlighted those non-military and non-specific insecurities about which actors in western Europe worried and to which they sought to respond through European integration. To quote Bill McSweeney:

17 See, Jutta Weldes, "Introduction: Constructing Insecurity," in Cultures of Insecurity: States, Communities, and the Production of Danger, ed. Jutta Weldes (Minneapolis: University of Minnesota Press, 1999), 11.

18 See, among others, Michael N. Barnett, "Culture, Strategy and Foreign Policy Change: Israel's Road to Oslo," European Journal of International Relations 5, no. 1 (1999), Roxanne Lynn Doty, "Foreign Policy as Social Construction: A Post-Positivist Analysis of US Counterinsurgency Policy in the Philippines," International Studies Quarterly 37, no. 3 (1993), Vendulka Kubálková, ed., Foreign Policy in a Constructed World (New York: ME Sharpe, 2001), Weldes, "Constructing National Interests.", Weldes, "The Cultural Production of Crises.", Jutta Weldes and Diana Saco, "Making State Action Possible: The United States and the Discursive Construction of 'the Cuban Problem', 1960-1994," MillenniumJournal of International Studies 25, no. 2 (1996).

19 See, for example, Ken Booth, "Security and Emancipation," Review of International Studies 17, no. 4 (1991), Ken Booth, Critical Security Studies and World Politics, (Boulder: Lynne Rienner: 2005), Ken Booth, Theory of World Security (Cambridge: Cambridge University Press, 2007), Barry Buzan, People, States, and Fear: An Agenda for International Security Studies in the Post-Cold War Era (New York: Harvester Wheatsheaf, 1991), Barry Buzan, Ole Waever, and Jaap de Wilde, Security: A New Framework for Analysis (Boulder: Lynne Rienner, 1998), Ole Waever, "Societal Security: The Concept," in Identity, Migration, and the New Security Agenda in Europe, ed. Ole Waever (London: Pinter, 1993). 
Whatever the personal motives of the individuals who founded it, the EU was a security policy from its inception. Even with the calculated exclusion of military defence, the process of integration itself bound the member-states in a network of interdependence which made the recourse to military means of resolving disputes progressively more difficult. ${ }^{20}$

The threat to which western European actors were responding was nonspecific and non-military, because, unlike NATO's targeting of possible Soviet expansionism, they had a less visible enemy. They sought to respond to those insecurities that might follow a possible return to past conflicts structured around old conceptions of identity and interests. ${ }^{21}$ That the threat to which they were responding was non-military and non-specific did not render it less real for the likes of Jean Monnet and Robert Schuman, who feared a return to Europe's own past. ${ }^{22}$ Specific domestic and foreign policy acts that made European integration possible hinged upon this Foreign Policy that identified Europe's own past as an other. Analyses that focus exclusively on the material aspects of security, however, have not been able to fully capture western European insecurities as such.

\section{Turkey's insecurities and its international relations}

A similar materialist bias prevails in the study of Turkey's international relations. An overview of the classics on Turkey's foreign policy reveals a focus on specific military insecurities - consider, for example, the treatises on Atatürk's policy-making as a response to the insecurities of the Ottoman past, and on Cold War policies as a response to Soviet expansionism. ${ }^{23}$ What remains under-examined are those non-military and non-specific insecurities that have also shaped Turkey's Foreign Policy

20 McSweeney, Security, Identity and Interests, 7.

21 Ibid. Also see, Ole Waever, "Identity, Integration and Security: Solving the Sovereignty Puzzle in EU Studies," Journal of International Affairs 48, no. 2 (1995), Ole Waever, "Insecurity, Security, and Asecurity in the West European Non-War Community," in Security Communities, ed. Emanuel Adler and Michael N. Barnett (Cambridge: Cambridge University Press, 1998).

22 Waever, "Insecurity, Security, and Asecurity."

23 See, inter alia, Mehmet Gönlübol and Cem Sar, Atatürk ve Türkiye'nin Dış Politikası (1919-1938) (Ankara: Atatürk Kültür, Dil ve Tarih Yüksek Kurumu, Atatürk Araştırma Merkezi, 1990), Ömer Kürkçüoğlu, "An Analysis of Atatürk's Foreign Policy, 1919-1938," Milletlerarası Münasebetler Türk Yıllığı 20 (1980-1981), Haluk Ülman and Oral Sander, "Türk Dış Politikasına Yön Veren Etkenler," Siyasal Bilgiler Fakültesi Dergisi 27, no. 1 (1972), Oral Sander, Türkiye'nin Dış Politikası (Ankara: İmge Yayıncılık, 1998). For up-to-date analyses of Turkey's foreign policies, see, Baskın Oran, ed., Türk Dış Politikası: Kurtuluş Savaşından Bugüne Olgular, Belgeler, Yorumlar, 9 ed., 2 vols. (İstanbul: İletişim, 2002), Hüseyin Bağcı, Zamanın Ruhu: Küresel Politika ve Türkiye Yazıları (Ankara: Orion, 2007). 
and foreign policy (as with the European/International Society's ambivalence towards Turkey's difference, see below). ${ }^{24}$

Second, even though Turkey's western orientation is considered a factor in the analysis of its foreign policy, this orientation's role in the mutually constitutive relationship between in/security and identity is rarely discussed. Indeed, those analyzing the role that identity plays in the shaping of security dynamics often do this in culturalist terms that is, by falling back into treating identity as a given and immutable independent variable, as a determinant of foreign policy. Despite introductory disclaimers, such writings often overlook the constructed nature of identity and the mutually constitutive relationship between in/security and identity. ${ }^{25}$

Third, an emerging literature that explores the mutually constitutive relationship between in/security and identity, treating both as dependent variables, has traced how Turkey has sought to locate itself in the West, as opposed to the non-West. ${ }^{26}$ This literature has proven insightful in so far as it has revealed the consequences of Turkey's Foreign Policy on its foreign policy. ${ }^{27}$ What this literature has so far overlooked are the insecurities that shaped Turkey's Foreign Policy in the first instance. ${ }^{28}$

24 See Ali L. Karaosmanoğlu's groundbreaking analysis on the issue, Ali L. Karaosmanoğlu, "The Evolution of the National Security Culture and the Military in Turkey," Journal of International Affairs 54, no. 1 (2000). While the author emphasizes the significance of insecurities to the Ottoman Empire's shift from considering Europe as unworthy of diplomatic representation to seeking membership in the Concert of Europe, his emphasis is on battleground losses. However, non-material insecurities (as with the European/International Society's refusal to recognize the Ottoman Empire as fully sovereign, notwithstanding its membership to the Concert of Europe) are not discussed. Yet, negotiating their difference internationally in the face of the European/International Society's ambivalence towards their difference was one of the dynamics behind the abovementioned shift in the Ottoman stance visà-vis Europe. See, Selim Deringil, The Well-Protected Domains: Ideology and the Legitimation of Power in the Ottoman Empire, 1876-1909 (London: I. B. Tauris, 1998).

25 See, for example, Hasan Kösebalaban, "The Permanent 'Other': Turkey and the Question of European Identity," Mediterranean Quarterly 18, no. 4 (2007): 110.

26 See, for example, Bahar Rumelili, "Constructing Identity and Relating to Difference: Understanding the EU's Mode of Differentiation," Review of International Studies 30, no. 1 (2004), Bahar Rumelili, "Negotiating Europe: EU-Turkey Relations from an Identity Perspective," Insight Turkey 10, no. 1 (2008), PInar Bilgin, "A Return to 'Civilisational Geopolitics' in the Mediterranean? Changing Geopolitical Images of the European Union and Turkey in the Post-Cold War Era," Geopolitics 9, no. 2 (2004). For a discussion with reference to the 'Eastern' dimension to Turkey's security/identity conundrum, see, Meliha B. Altunışık and Özlem Tür, "From Distant Neighbours to Partners? Changing SyrianTurkish Relations," Security Dialogue 37, no. 2 (2006).

27 Following the end of the Cold War and the disappearance of the West, vis-à-vis which Turkey's westernness had been reaffirmed, Turkey's identity politics ran into difficulty. See, Gülnur Aybet and Meltem Müftüler-Baç, "Transformations in Security and Identity after the Cold War: Turkey's Problematic Relationship with Europe," International Journal 55, no. 4 (2000).

See the final part of this section for further discussion. 
An appreciation for Turkey's insecurities in the analysis of its international relations lies at the heart of this article. While the military insecurities that Turkey has experienced and the specific foreign policy acts designed in response to them have been accounted for in the literature, ${ }^{29}$ non-military and non-specific insecurities that have also shaped Turkey's international relations have been left unexamined. This article constitutes a preliminary inquiry in this direction. For reasons of space, no detailed account of Turkey's western orientation or its insecurities will be presented here.

Taking my cue from how critical approaches render European integration a response to insecurities of a non-military and nonspecific nature, in the following, I will offer a preliminary reading of Turkey's Foreign Policy as a response to non-military and non-specific insecurities of the early Republican era. The threat to the Republic of Turkey was non-military in that the gains of the National Struggle had been sealed through the Lausanne Treaty of 1923. Yet, while Lausanne had reaffirmed Turkey's hard-won sovereignty, independence and territorial integrity, the founding leaders were nevertheless concerned about the fragility of such recognition, given the European/International Society's ambivalence toward their difference. ${ }^{30}$ The threat to which they sought to respond was non-specific in that they were not targeting a specific act of a specific counterpart. Rather, they responded to what the future may bring, based on their particular remembrances of the past and interpretations of the present. One such remembrance was that non-military insecurities (the withholding of recognition as a full member of the European/International Society) had consequences for military security (instances of military intervention and/or loss of sovereignty experienced in some parts of Asia and Africa). Thus, Turkey's international relations came to rest on the West/non-West divide partly as a response to non-military and non-specific insecurities vis-à-vis the European/ International Society.

This is not how the story is usually told. Turkey is invariably represented as having turned to the West only after World War II and as part of an attempt to avoid being integrated into the Eastern Bloc by the

29 See, inter alia, Tamkoç, "Turkey's Quest for Security through Defensive Alliances.", Tamkoç, The Warrior Diplomats, Karaosmanoğlu, "The Evolution of the National Security Culture.", Duygu B. Sezer, “Turkey's Security Policies," Adelphi Papers, no. 164 (1981).

30 Such ambivalence has been read differently in various political science and history accounts. Consider, among others, Aslı Çırakman, From the "Terror of the World" to the "Sick Man of Europe": European Images of Ottoman Empire and Society from the Sixteenth Century to the Nineteenth (New York: Peter Lang, 2002), Deringil, The Well-Protected Domains. 
Soviet Union. Indeed, Turkey's international relations until 1939 were characterized as one of "relative autonomy,"31 and between 1939 and 1945 as one of "active neutrality." ${ }^{2}$ Thus, Turkey's NATO membership (1952) is viewed as the turning point in the history of its international relations by enthusiasts as well as critics of its Western orientation. However, while the founding leaders' pragmatism meant refraining from foreign policy acts that would have tied Turkey to one allegiance well until the end of WWII, Turkey's Foreign Policy was far less ambiguous throughout this period. From its inception, Turkey's Foreign Policy has rested on the West/non-West divide. That is to say, while Turkey's Western-oriented foreign policy did not crystallize until the years before World War II, its Foreign Policy took an explicitly Western turn as early as in the 1920 s.

While Turkey's modernization and/or westernization have been analyzed in great detail, ${ }^{33}$ insecurities of a non-military and non-specific kind have remained unarticulated. Put differently, if "the conceptualization of the West, whether as an idealisation or as an accusation, influences directly the praxis of social actors" in Turkey (and elsewhere), ${ }^{34}$ it is not only due to domestic political dynamics (as with the desire to benefit from the fruits of the Enlightenment, or the wish to emulate the success of the nation-state model), or to the urge to escape battlefield losses, but also because of the ambivalent attitude of the European/International Society vis-à-vis non-western others.

\section{Encounters with European/international society as a source of insecurity}

A growing body of critiques of the International Society School (also known as the English School) have looked at, among other things, Europe's encounter with non-Europeans and their mutual transformation. Particularly insightful are critical accounts of the period during which the Chinese, Japanese and Ottoman empires sought membership in the European/International Society. In contrast to mainstream Internation-

31 Baskın Oran, "Dönemin Bilançosu," in Türk Dış Politikası: Kurtuluş Savaşından Bugüne Olgular, Belgeler, Yorumlar, ed. Baskın Oran (İstanbul: İletişim, 2002), 257, Mehmet Gönlübol, ed., Olaylarla Türk Dış Politikası (Ankara: Siyasal Bilgiler Fakültesi, 1969), William Hale, Turkish Foreign Policy, 17442000 (London: Frank Cass, 2000).

32 Selim Deringil, Turkish Foreign Policy during the Second World War: An Active Neutrality (Cambridge: Cambridge University Press, 1989).

33 See footnote 6.

34 Nilüfer Göle, "Engineers: Technocratic Democracy," in Turkey and the West: Changing Political and Cultural Identities, ed. Metin Heper, Ayşe Öncü, and Heinz Kramer (London: I. B. Tauris, 1993). For cases other than Turkey, see, for example, Sankaran Krishna, Postcolonial Insecurities: India, Sri Lanka, and the Question of Nationhood (Minneapolis: University of Minnesota Press, 1999), Timothy Mitchell, ed., Questions of Modernity (Minneapolis: University of Minnesota Press, 2000). 
al Society writings - which have explained the expansion of the European/International Society as one of a benevolent Europe exporting its values and institutions of civilized statecraft, and/or non-Europeans "adhering to the common interests and values, binding rules and institutions of the nineteenth-century international society which self-consciously characterised itself as 'civilized" 35 - non-western encounters with the European/International Society were suffused with insecurities. ${ }^{36}$ Reactions to the portrayal of the non-western as not deserving to rule (by virtue of being less-than-civilized) and the interlinked European claim to better rule had taken various forms, including the search for removing the grounds for the claim to such superiority. Indeed, in an unequal setting where the hierarchical binaries of western/eastern or civilized/less-than-civilized were defined by the powerful, feigning similarity, seemingly becoming and being modern, civilized, western often emerged as a primal form of response. ${ }^{37}$ The non-western often resorted to feigning similarity, because it was on the basis of a hierarchical classification of nations (civilized vs. less-than-civilized) that colonialism had been justified for years. ${ }^{38}$

The critics of the International Society School thus help us understand post-colonial insecurities by way of decoding the survival tactics adopted to escape colonization and/or intervention of one form or another. As such, they help highlight the mutual transformation in the identities and interests of westerners and non-westerners, as the latter struggled to pass the test of a standard of civilization set by the former. Providing a full account of the insights of post-colonial critique is beyond the scope of this article. Let me focus, by way of illustration, on the concept of civilization, which was also central to the discourses of Turkey's founding leaders.

35 Gerrit W. Gong, "China's Entry into International Society," in The Expansion of International Society, ed. Hedley Bull and Adam Watson (Oxford: Clarendon Press, 1984). Also see the other contributions to Hedley Bull and Adam Watson, eds., The Expansion of International Society (Oxford: Clarendon Press, 1984).

36 See, Yongjin Zhang, "China's Entry into International Society: Beyond the Standard of 'Civilization', " Review of International Studies 17 (1991), Antony Anghie, Imperialism, Sovereignty and the Making of International Law (Cambridge: Cambridge University Press, 2005), Shogo Suzuki, Civilisation and Empire: China and Japan's Encounter with European International Society (London: Routledge, 2009).

37 Homi K. Bhabha, The Location of Culture (London: Routledge, 1994), L. H. M. Ling, Postcolonial International Relations: Conquest and Desire between Asia and the West (Houndmills: Palgrave, 2002), L. H. M. Ling, "Cultural Chauvinism and the Liberal International Order: "West vs. Rest" In Asia's Financial Crisis," in Power in a Postcolonial World: Race, Gender and Class in International Relations, ed. Geeta Chowdhry and Sheila Nair (London: Routledge, 2002).

38 This reading does not in any way rule out and/or diminish other concerns behind modernization and/ or westernization. Rather, it points to an additional aspect. 
The International Society is an institution that originated in the practices of European states. These practices were initially designed to regulate affairs among Christian states of Europe so as to minimize friction and violence. As religious concerns gave way to secular ones in an attempt to remove religious arguments from the realm of politics, ${ }^{39}$ Christianity disappeared as the primary marker of the identity of the European/International Society and was replaced by "civilization." The need for regulating relations with non-Europeans led to the emergence of a set of criteria referred to as the "standards of civilization," detailing what Europeans expected from non-Europeans if they wished to be a part of and benefit from the privileges that membership accrued. ${ }^{40}$

In International Society terms, standards of civilization refer to "the assumptions, tacit and explicit, used to distinguish those that belong to a particular society (by definition the 'civilised')." ${ }^{11}$ Initially formulated to overcome the obstacles European actors encountered in their dealings with Others, the standards of civilization also proved instrumental for some imperial powers in their colonial dealings. ${ }^{42}$ While those who were altogether outside the European/International Society were considered not deserving of self-governance (as with parts of Asia and Africa), others in the process of meeting the standards with a view to joining endured intervention of one form or another (such as China and Japan).

\section{Early republican insecurities vis-à-vis European/international society}

Although the literature points to the year 1856 as the date when the Ottoman Empire was recognized as having passed the test of the standards of civilization and gained entry into the European/International Society, ${ }^{43}$ the fact that capitulations remained in place suggests that the empire was still considered a less-than-full member. ${ }^{44}$ The Republic of

39 Michael C. Williams, "Identity and the Politics of Security," European Journal of International Relations 4, no. 2 (1998).

40 Hedley Bull, The Anarchical Society (London: Macmillan, 1977), Bull and Watson, eds., The Expansion of International Society, Gerrit W. Gong, The Standard of "Civilization" in International Society (Oxford: Clarendon Press, 1984).

41 Gong, "China's Entry into International Society."

42 After all, non-western Others were not always more tolerant towards difference or accepting of equality in treatment. See, Hedley Bull's foreword to Gong, The Standard of "Civilization" in International Society Also see, Deringil, “'They Live in a State of Nomadism and Savagery'.", Ling, Postcolonial International Relations, Suzuki, Civilisation and Empire.

43 See, Thomas Naff, "The Ottoman Empire and the European States System," in The Expansion of International Society, ed. Hedley Bull and Adam Watson (Oxford: Clarendon Press, 1984). Also see, A. Nuri Yurdusev, "The Ottoman Attitude toward Diplomacy," in Ottoman Diplomacy: Conventional or Unconventional?, ed. A. Nuri Yurdusev (Houndmills: Palgrave, 2004), Fikret Adanır, "Turkey's Entry into the Concert of Europe," European Review 13, no. 3 (2005).

44 Capitulations were granted by the sultan in an earlier era, when the Ottoman Empire was at the peak 
Turkey inherited some of these concerns by virtue of being a successor to the Ottoman Empire, ${ }^{45}$ and its founding leaders' formative years having been shaped by the Ottoman ordeal. ${ }^{46}$ In the following, I will suggest that the Foreign Policy of locating Turkey firmly in the West as opposed to the non-West was partly a response to insecurities. The newly established republic was in need of recognition as an equal by the great powers of Europe (a non-material threat), thereby removing the grounds for intervention and making room for sovereign development (a material threat).

Initial encounters of Turkey's founding leaders with the ambivalence of the European/International Society towards their difference occurred during the National Struggle when, in the words of Enver Ziya Karal,

the Allies did not hesitate to use civilisation themselves as a propaganda instrument to divide Turkey. They claimed that the Turks in history had never been the creators of any masterpieces of civilisation. Furthermore, they claimed that the Turks had always been strangers to Western civilisation and had even attempted to destroy it. This propaganda resulted in the claim that Turks did not deserve to survive as an independent nation. ${ }^{47}$

Such ambivalence remained even after the National Struggle had come to an end. One of the thorniest issues at Lausanne was the capitulations. Particularly distressful for the team representing Turkey had been their western counterparts' reasoning that the capitulations had had to remain in place, because "Turkey was a backward country and still under Islamic law." 48

European actors' propaganda during the National Struggle and the difficulties encountered during the Lausanne Treaty negotiations seem to have driven home the lesson that winning the war on the battlefield

of its military power. Over time, the power balance shifted between the Ottoman Empire and its European counterparts. They were removed with the signing of the Lausanne Treaty.

45 See, Metin Heper, "The Ottoman Legacy and Turkish Politics," Journal of International Affairs 54, no. 1 (2000).

46 See, Frederick W. Frey, The Turkish Political Elite (Cambridge: MIT Press, 1965). The final stages of the Ottoman ordeal are documented in Illber Ortaylı, Imparatorluğun En Uzun Yüzyılı (İstanbul: Hil Yayınları, 1983).

47 Enver Ziya Karal, "The Principles of Kemalism," in Atatürk: The Founder of a Modern State, ed. Ali Kazancigil and Ergun Özbudun (Hamden: Archon Books, 1981).

48 Cited in Andrew Davison, Secularism and Revivalism in Turkey: A Hermeneutic Reconsideration (New Haven: Yale University Press, 1998). On Lausanne negotiations, see, Ali Naci Karacan, Lozan Konferansı ve Ismet Paşa (İstanbul: İstanbul Maarif Matbaası, 1943), Metin Heper, Ismet Inönü: The Making of a Turkish Statesman (Leiden: Brill, 1998). 
and the negotiating table were not enough, unless the grounds for the European/International Society's claim to better rule was removed as well. Halil İnalcak has highlighted the parallels during this period "between Turkish claims to be a fully independent modern nation-state and as such to ask for equal treatment at Lausanne, and Kemal's promises of taking radical measures to modernise Turkey during his Anatolian tour in 1923." ${ }^{49}$ Recognizing not only the fragility of formal recognition by the European/International Society, but also the potential insecurities that were likely to follow in the eventuality of the withdrawal of such recognition, Mustafa Kemal Atatürk set the goal of lifting Turkey up to the level of contemporary civilization and set in motion a plan that involved organizing a conference on national economy (to express Turkey's commitment to liberal economy), convening of a committee for legal reforms (to signal the intention to adopt European law in civil matters), and going on a tour of Anatolia to discursively make the case for Turkey's modernization and secularization. ${ }^{50}$

The abovementioned critical scholars underscore the importance of battlefield gains when they note that it was not Ottoman efforts to meet the standards of civilization, but the military success of the $\mathrm{Na}$ tional Struggle that was decisive for Turkey eventually being recognized as fully sovereign. ${ }^{51}$ Yet, even though the National Struggle was won and formal recognition of Turkey as an independent and sovereign state achieved with the signing of the Treaty of Lausanne, Turkey's founding leaders remained apprehensive regarding the ambivalence in the European/International Society's treatment of the young republic. Consider the following quote by one of Atatürk's closest friends, Falih Rıfkı Atay, who put the choices facing Turkey at the time in dramatic terms: "We were either going to become European or [...] the seven-fanged imperialist beast called Düveli Muazzama [great powers of Europe] was going to break us up and turn into Asian hordes." 52 The national anthem of Turkey, which was adopted during the National Struggle, expressed similar sentiments in equally dramatic terms when it referred to Düveli Muazzama as "that one-fanged beast that you call civilization."53

49 See, Halil Inalcık, Turkey and Europe in History (İstanbul: Eren, 2006).

50 For a discussion on the securityness of secularism in Turkey, see, Pınar Bilgin, "The Securityness of Secularism? The Case of Turkey," Security Dialogue 39, no. 6 (2008).

51 Zhang, "China's Entry into International Society."

52 Falih Rıfkı Atay, Çankaya (Ankara: Bateş, 1980).

53 Here is the fourth verse of the ten-verse poem in full: "The lands of the West may be armored with walls of steel/ but I have borders guarded by the mighty chest of a believer./ Recognize your innate strength, my friend!/ And think: how can this fiery faith ever be killed/ by that battered, single-fanged monster you call civilization?" 
The ambivalence in the European/International Society's treatment of Turkey's difference found its match in the ambivalence of the Republican leaders' approach to the European/International Society. The West was a source of both inspiration and insecurity. Turkey's founding leaders considered themselves facing a predicament similar to the one faced by post-colonial peoples in other parts of the world; either feign similarity, or risk loss of full sovereignty and independence. Again, this is not to reduce Turkey's modernization and/or westernization to seeking similarity (understood in the everyday sense of the term), but to underscore the parallels in the experiences of various peoples in their encounters with the European/International Society.

The point made here is slightly different from the one frequently made in the literature regarding Atatürk's mistrust of European diplomacy. Atatürk is quoted to have said in the early years of the National Struggle that "our nation's fault is to have manifested over-confidence in the honesty of Europe." ${ }^{54}$ While such mistrust has been explained with reference to Atatürk's foreign policy stance of "no total confidence in friends or the outer world," 55 the productive tension between seeing the West as a source of inspiration as much as insecurity is better captured by the notion of ambivalence. ${ }^{56}$

\section{The significance of capturing ambivalence as a source of insecurity}

The otherwise rich literature detailing various aspects of Turkey's relations with the West/Europe has so far failed to fully capture the abovementioned ambivalence and insecurities that followed, for it has focused on highlighting Turkey's otherness to Europe, ${ }^{57}$ but not vice versa. The literature on Turkey's relations with the European Union, in turn, has focused on Turkey's quest for accession to European integration while overlooking the insecurities involved. Indeed, not even those who question the appropriateness of Turkey's goals question the dynamics behind this difficult relationship. ${ }^{58}$ Taken together, the apparent persistence

54 Cited in Kürkçüoğlu, "An Analysis of Atatürk's Foreign Policy," 138.

55 Ibid. Also see, Karaosmanoğlu, "The Evolution of the National Security Culture."

56 On Japan and China's handling of such ambivalence, see, Suzuki, Civilisation and Empire.

57 See, for example, Iver B. Neumann and Jennifer M. Welsh, "The Other in European Self-Definition: An Addendum to the Literature on International Society," Review of International Studies 17, no. 4 (1991), Iver B. Neumann, Uses of the Other: 'the East' in European Identity Formation (Minneapolis: Minnesota University Press, 1999), Nilüfer Göle, "Europe's Encounter with Islam: What Future?," Constellations 13, no. 2 (2006), Jose Casanova, "The Long, Difficult, and Tortuous Journey of Turkey into Europe and the Dilemmas of European Civilization," Constellations 13, no. 2 (2006).

58 See, for example, Barry Buzan and Thomas Diez, "The European Union and Turkey," Survival 41, no. 1 (1999). 
of some European actors' ambivalence regarding Turkey's difference, ${ }^{59}$ Turkish actors' particular remembrances of the past and interpretations for the present as colored by their own ambivalence, and their reaction to European rhetoric/behavior all underscore the need for further scrutinizing the dynamics behind Turkey's western orientation.

Failing to fully capture the centrality of Turkey's insecurities to its international relations is likely to have implications for our understanding of the future of Turkey's western orientation. For when Turkey's western orientation is reduced from being an identity choice (Foreign Policy) to mere Cold War policy preference (foreign policy), it becomes difficult to understand its enduring centrality for Turkey's international relations. Indeed, critics, including ambassador-without-portfolio Ahmet Davutoğlu, have been quick to argue that, now that the Cold War is over, Turkey need not put so much emphasis on the West, but instead should diversify its relations. ${ }^{60}$ Hence recent calls for Turkey to de-emphasize its western orientation.

While efforts to make Turkey's foreign policy more multi-dimensional go back as far as the 1960 s, ${ }^{61}$ Davutoğlu, among others, has articulated the need for a multi-dimensional outlook in terms of Turkey's historical and religio-cultural characteristics. His argument takes as predetermined what Turkey is ( Foreign Policy) and offers what its foreign policy should be. To re-state in the language of foreign policy analysis, while paying attention to the non-material dimension of international relations and thus seeming to adopt a critical perspective, Davutoğlu's argument is no less deterministic than prevalent approaches to foreign policy analysis in that the author treats identity as pre-given and immutable (that is, in culturalist terms). The only difference between Davutoğlu's account and prevalent approaches to foreign policy analysis consists of putting culture and identity in place of military threat, taken as pre-given. No room is left in Davutoğlu's account for the mutually constitutive relationship between in/security and identity.

Let me further clarify this point by referring to another author writing on the same subject:

On the one hand, by rejecting Turkey, Europe would stress its commitment to a culturally defined European identity with a sin-

59 See, for example, Elizabeth Shakman Hurd, "Negotiating Europe: The Politics of Religion and the Prospects of Turkish Accession," Review of International Studies 32 (2006).

60 Davutoğlu, Stratejik Derinlik.

61 Melek Fırat and Ömer Kürkçüoğlu, "Ortadoğu ile Iliş̧kiler," in Türk Dış Politikası, ed. Baskın Oran (İstanbul: iletişim, 2002). 
gular civilisational identity. On the other, by embracing Turkey, it would move beyond the cultural paradigm and transform itself to a geographically defined entity embracing a multiplicity of civilisations. ${ }^{62}$

While starting from a premise that acknowledges the constructed nature of identities, the author, by way of treating culture and civilization as pre-given and immutable, ends up denying the constructed nature of the categories upon which he builds his argument. Therefore, the author's treatment of identity comes across as no less culturalist.

Even though Turkey's preference for identifying itself as western has ended up alienating some parts of the non-West and resulted in foregoing the capital of a potentially more cosmopolitan identity that embraces its own interstitiality, ${ }^{63}$ this need not render research into the dynamics behind the choice of that specific Foreign Policy a historical curiosity. It remains to be argued whether such insecurities have lost their relevance in contemporary world politics altogether. For, while Turkey embracing its interstitiality is a cause for celebration in the eyes of some European actors, ${ }^{64}$ it remains a source of insecurity to others, given their ambivalence towards difference. Be that as it may be in the policy realm, this article has made a case for the relevance of understanding the centrality of western orientation to Turkey's international relations.

\section{Conclusion}

Turkey's western orientation has yet another dimension so far barely examined in the literature - that of in/security of the non-military and non-specific kind. Even before Turkey began to follow an explicitly western-oriented foreign policy, its Foreign Policy had taken a westward turn - by virtue of the founding leaders' efforts to locate Turkey in contemporary civilization. Turkey's western-oriented Foreign Policy, as this article has argued, was a crucial aspect of its search for security in the face of a European/International Society that had, in the past, refused equal treatment to the Ottoman Empire. At the time, the Foreign Policy of locating Turkey in the West allowed the founding leaders to claim the right to be treated equally and with respect. Furthermore, this Foreign Policy allowed for more specific acts of western-oriented foreign policy in the following years - as with the decision to join the Anglo-French

62 Kösebalaban, "The Permanent 'Other'."

63 Rumelili, "Negotiating Europe."

64 This is so either because they believe in a true self (culturalist), or because they take interstitiality to be a cosmopolitan stance. 
alliance on the eve of World War II, to become a member of NATO in 1952, and to seek European Union membership.

The non-specific and non-military security problem encountered by Turkey's founding leaders was one of negotiating their difference internationally in the face of the European/International Society's ambivalence towards their difference. A solution was found in lifting Turkey to the level of contemporary civilization. That civilization no longer carries the same meaning as it did in the late nineteenth and early twentieth century need not render such analysis less significant. ${ }^{65}$ Nor does it diminish the significance of the notion of (standards of) civilization for world politics. As Gerrit W. Gong reminds us,

The standard of civilisation is not just a historical curiosity, an idea important only to a bygone era, significant as it may have been [...] Insights into the extent to which the standard of 'civilisation' was forcibly imposed, reluctantly accepted, or eagerly embraced are essential to understanding the underlying structural strengths and weaknesses of today's international society. ${ }^{66}$

The fact that the insecurities experienced by non-westerners were nonmilitary and non-specific does not render them less real. The insecurities that shaped Turkey's Foreign Policy at the time of its founding were very real. Moreover, they remain essential to understanding Turkey's present-day international relations.

\section{References}

Adanır, Fikret. "Turkey's Entry into the Concert of Europe." European Review 13, no. 3 (2005): 395-417.

Allison, Graham T. Essence of Decision: Explaining the Cuban Missile Crisis. Boston: Little, 1971.

Allison, Graham T., and Philip Zelikow. Essence of Decision: Explaining the Cuban Missile Crisis. New York: Longman, 1999.

Altunışık, Meliha B., and Özlem Tür. "From Distant Neighbours to Partners? Changing Syrian-Turkish Relations." Security Dialogue 37, no. 2 (2006): 229-48.

Anghie, Antony. Imperialism, Sovereignty and the Making of International Law. Cambridge: Cambridge University Press, 2005.

Atay, Falih Rıfkı. Çankaya. Ankara: Bateş, 1980.

Aybet, Gülnur. "Turkey and the EU after the First Year of Negotiations: Reconciling Internal and External

65 Not the least because a degree of ambivalence is still apparent in some European policy-makers' discourse. Consider Italian Prime Minister Berlusconi's statement in the aftermath of 9/11. He said: "We must be aware of the superiority of our civilisation, a system that has guaranteed well-being, respect for human rights and — in contrast with Islamic countries — respect for religious and political rights, a system that has as its value understanding of diversity and tolerance." See, "EU deplores "dangerous" Islam jibe'," (2002), http://news.bbc.co.uk/1/hi/world/middle_east/1565664.stm. 
Policy Challenges." Security Dialogue 37, no. 4 (2006): 529-49.

Aybet, Gülnur, and Meltem Müftüler-Baç. "Transformations in Security and Identity after the Cold War:

Turkey's Problematic Relationship with Europe.” International Journal 55, no. 4 (2000): 567-82.

Bağcı, Hüseyin. Zamanın Ruhu: Küresel Politika ve Türkiye Yazıları. Ankara: Orion, 2007.

Barnett, Michael N. "Culture, Strategy and Foreign Policy Change: Israel's Road to Oslo." European Journal of International Relations 5, no. 1 (1999): 5-36.

Bhabha, Homi K. The Location of Culture. London: Routledge, 1994.

Bilgin, Pınar. "A Return to 'Civilisational Geopolitics' in the Mediterranean? Changing Geopolitical Images of the European Union and Turkey in the Post-Cold War Era." Geopolitics 9, no. 2 (2004): 269-91.

. "The Securityness of Secularism? The Case of Turkey." Security Dialogue 39, no. 6 (2008): 593-614.

Booth, Ken. Critical Security Studies and World Politics, Boulder. Lynne Rienner, 2005.

—. "Security and Emancipation." Review of International Studies 17, no. 4 (1991): 313-26.

- Theory of World Security. Cambridge: Cambridge University Press, 2007.

Bozdoğan, Sibel, and Reşat Kasaba, eds. Rethinking Modernity and National Identity in Turkey. Seattle: University of Washington Press, 1997.

Bull, Hedley. The Anarchical Society. London: Macmillan, 1977.

Bull, Hedley, and Adam Watson, eds. The Expansion of International Society. Oxford: Clarendon Press, 1984.

Buzan, Barry. People, States, and Fear: An Agenda for International Security Studies in the Post-Cold War Era. New York: Harvester Wheatsheaf, 1991.

Buzan, Barry, and Thomas Diez. "The European Union and Turkey." Survival 41, no. 1 (1999): 41-57.

Buzan, Barry, Ole Waever, and Jaap de Wilde. Security: A New Framework for Analysis. Boulder: Lynne Rienner, 1998.

Campbell, David. Writing Security: United States Foreign Policy and the Politics of Identity. Manchester: Manchester University Press, 1992.

Casanova, Jose. "The Long, Difficult, and Tortuous Journey of Turkey into Europe and the Dilemmas of European Civilization." Constellations 13, no. 2 (2006): 243-47.

Çırakman, Aslı. From the "Terror of the World" to the "Sick Man of Europe": European Images of Ottoman Empire and Society from the Sixteenth Century to the Nineteenth. New York: Peter Lang, 2002.

Davison, Andrew. Secularism and Revivalism in Turkey: A Hermeneutic Reconsideration. New Haven: Yale University Press, 1998.

Davutoğlu, Ahmet. Stratejik Derinlik. İstanbul: Küre Yayınları, 2001.

Deringil, Selim. “'They Live in a State of Nomadism and Savagery': The Late Ottoman Empire and the Post-Colonial Debate." Comparative Studies in Society and History 45, no. 2 (2003): 311-42.

- Turkish Foreign Policy during the Second World War: An Active Neutrality. Cambridge: Cambridge University Press, 1989.

- The Well-Protected Domains: Ideology and the Legitimation of Power in the Ottoman Empire, 18761909 London: I. B. Tauris, 1998.

Doty, Roxanne Lynn. "Foreign Policy as Social Construction: A Post-Positivist Analysis of US Counterinsurgency Policy in the Philippines." International Studies Quarterly 37, no. 3 (1993): 297-320.

Erozan, Boğaç, and İlter Turan. "The Development of Political Science in Turkey." PS (April 2004): 359 63.

“"EU deplores “dangerous” Islam jibe'.” (2002), http://news.bbc.co.uk/1/hi/world/middle_east/1565664. stm.

Fırat, Melek, and Ömer Kürkçüoğlu. "Ortadoğu ile Iliş̧kiler." In Türk Dış Politikası, edited by Baskın Oran, 784-96. İstanbul: İletişim, 2002.

Frey, Frederick W. The Turkish Political Elite. Cambridge: MIT Press, 1965.

Fuller, Graham E. "Turkey's New Eastern Orientation." In Turkey's New Geopolitics: From the Balkans to Western China, edited by Graham E. Fuller and Ian O. Lesser, 33-97, 1993.

Gong, Gerrit W. "China's Entry into International Society." In The Expansion of International Society, edited by Hedley Bull and Adam Watson, 171-83. Oxford: Clarendon Press, 1984.

- The Standard of "Civilization" in International Society Oxford: Clarendon Press, 1984.

Göle, Nilüfer. "Engineers: Technocratic Democracy." In Turkey and the West: Changing Political and Cultural Identities, edited by Metin Heper, Ayşe Öncü and Heinz Kramer. London: I. B. Tauris, 1993.

_. "Europe's Encounter with Islam: What Future?" Constellations 13, no. 2 (2006): 248-62. 
Gönlübol, Mehmet, ed. Olaylarla Türk Dış Politikası. Ankara: Siyasal Bilgiler Fakültesi, 1969.

Gönlübol, Mehmet, and Cem Sar. Atatürk ve Türkiye'nin Dış Politikası (1919-1938). Ankara: Atatürk Kültür, Dil ve Tarih Yüksek Kurumu, Atatürk Araştırma Merkezi, 1990.

Hale, William. Turkish Foreign Policy, 1744-2000. London: Frank Cass, 2000.

Heper, Metin. Ismet Inönü: The Making of a Turkish Statesman. Leiden: Brill, 1998.

—. "The Ottoman Legacy and Turkish Politics." Journal of International Affairs 54, no. 1 (2000): 63-86.

Heper, Metin, Ayşe Öncü, and Heinz Kramer, eds. Turkey and the West: Changing Political and Cultural Identities. New York: I. B. Tauris, 1993.

Hudson, Valerie. Foreign Policy Analysis: Yesterday, Today and Tomorrow. Lanham: Rowman \& Littlefield, 2007.

Huntington, Samuel P. “Clash of Civilizations?” Foreign Affairs 72, no. 3 (1993): 22-28.

Hurd, Elizabeth Shakman. "Negotiating Europe: The Politics of Religion and the Prospects of Turkish Accession." Review of International Studies 32 (2006): 401-18.

Inalcık, Halil. Turkey and Europe in History. İstanbul: Eren, 2006.

Jervis, Robert. Perception and Misperception in International Politics. Princeton: Princeton University Press, 1976.

Karacan, Ali Naci. Lozan Konferansı ve Ismet Paşa. İstanbul: İstanbul Maarif Matbaası, 1943.

Karal, Enver Ziya. "The Principles of Kemalism." In Atatürk: The Founder of a Modern State, edited by Ali Kazancigil and Ergun Özbudun, 11-35. Hamden: Archon Books, 1981.

Karaosmanoğlu, Ali L. "The Evolution of the National Security Culture and the Military in Turkey." Journal of International Affairs 54, no. 1 (2000): 199-216.

Kösebalaban, Hasan. "The Permanent 'Other': Turkey and the Question of European Identity." Mediterranean Quarterly 18, no. 4 (2007): 87-111.

Krishna, Sankaran. Postcolonial Insecurities: India, Sri Lanka, and the Question of Nationhood. Minneapolis: University of Minnesota Press, 1999.

Kubálková, Vendulka, ed. Foreign Policy in a Constructed World. New York: ME Sharpe, 2001.

Kürkçüoğlu, Ömer. “An Analysis of Atatürk's Foreign Policy, 1919-1938.” Milletlerarası Münasebetler Türk Yıllığı 20 (1980-1981): 133-87.

Laffey, Mark. "Locating Identity: Performativity, Foreign Policy and State Action." Review of International Studies 26, no. 3 (2000): 429-44.

Ling, L. H. M. "Cultural Chauvinism and the Liberal International Order: "West vs. Rest" In Asia's Financial Crisis." In Power in a Postcolonial World: Race, Gender and Class in International Relations, edited by Geeta Chowdhry and Sheila Nair, 115-40. London: Routledge, 2002.

- Postcolonial International Relations: Conquest and Desire between Asia and the West. Houndmills: Palgrave, 2002.

McSweeney, Bill. Security, Identity and Interests: A Sociology of International Relations. Cambridge: Cambridge University Press, 1999.

Mitchell, Timothy, ed. Questions of Modernity. Minneapolis: University of Minnesota Press, 2000.

Naff, Thomas. "The Ottoman Empire and the European States System." In The Expansion of International Society, edited by Hedley Bull and Adam Watson, 143-69. Oxford: Clarendon Press, 1984.

Neumann, Iver B. Uses of the Other: 'the East' in European Identity Formation. Minneapolis: Minnesota University Press, 1999.

Neumann, Iver B., and Jennifer M. Welsh. "The Other in European Self-Definition: An Addendum to the Literature on International Society." Review of International Studies 17, no. 4 (1991): 327-40.

Oran, Baskın. “Dönemin Bilançosu.” In Türk Dış Politikası: Kurtuluş Savaşından Bugüne Olgular, Belgeler, Yorumlar, edited by Baskın Oran. İstanbul: Illetişim, 2002.

— - ed. Türk Dış Politikası: Kurtuluş Savaşından Bugüne Olgular, Belgeler, Yorumlar. 9 ed. 2 vols. İstanbul: İletişim, 2002.

Ortaylı, i̇lber. Imparatorluğun En Uzun Yüzyılı. İstanbul: Hil Yayınları, 1983.

Parla, Taha, and Andrew Davison. Corporatist Ideology in Kemalist Turkey. Syracuse: Syracuse University Press, 2004

Rumelili, Bahar. "Constructing Identity and Relating to Difference: Understanding the EU's Mode of Differentiation." Review of International Studies 30, no. 1 (2004): 27-47. . "Negotiating Europe: EU-Turkey Relations from an Identity Perspective." Insight Turkey 10, no. 1 (2008): 97-110. 
Sander, Oral. Türkiye'nin Dış Politikası. Ankara: İmge Yayıncılık, 1998.

Sezer, Duygu B. "Turkey's Security Policies." Adelphi Papers, no. 164 (1981).

Suzuki, Shogo. Civilisation and Empire: China and Japan's Encounter with European International Society. London: Routledge, 2009.

Tamkoç, Metin. “Turkey's Quest for Security through Defensive Alliances.” Milletlerarası Münasebetler Türk Yıllığı 2 (1961): 1-39.

- The Warrior Diplomats: Guardians of National Security and Modernization of Turkey. Salt Lake City: University of Utah Press, 1976.

Taşpınar, Ömer. “The Old Turks' Revolt.” Foreign Affairs 86, no. 6 (2007): 114-30.

Tunander, Ola. "A New Ottoman Empire? The Choice for Turkey: Euro-Asian Centre vs National Fortress." Security Dialogue 26, no. 4 (1995): 413-27.

Ülman, Haluk, and Oral Sander. "Türk Dış Politikasına Yön Veren Etkenler.” Siyasal Bilgiler Fakültesi Dergisi 27 , no. 1 (1972): 1-24.

Waever, Ole. "Identity, Integration and Security: Solving the Sovereignty Puzzle in EU Studies." Journal of International Affairs 48, no. 2 (1995): 389-431.

- "Insecurity, Security, and Asecurity in the West European Non-War Community." In Security Communities, edited by Emanuel Adler and Michael N. Barnett, 69-118. Cambridge: Cambridge University Press, 1998.

. "Societal Security: The Concept." In Identity, Migration, and the New Security Agenda in Europe, edited by Ole Waever, 17-40. London: Pinter, 1993.

Weldes, Jutta. "Constructing National Interests." European Journal of International Relations 2, no. 3 (1996): 275-318.

—. "The Cultural Production of Crises: US Identity and Missiles in Cuba." In Cultures of Insecurity: States, Communities, and the Production of Danger, edited by Jutta Weldes, 35-62. Minneapolis: University of Minnesota Press, 1999.

—. "Introduction: Constructing Insecurity." In Cultures of Insecurity: States, Communities, and the Production of Danger, edited by Jutta Weldes. Minneapolis: University of Minnesota Press, 1999.

Weldes, Jutta, and Diana Saco. "Making State Action Possible: The United States and the Discursive Construction of 'the Cuban Problem', 1960-1994." Millennium-Journal of International Studies 25, no. 2 (1996): 361-95.

Williams, Michael C. "Identity and the Politics of Security." European Journal of International Relations 4, no. 2 (1998): 204-25.

Yurdusev, A. Nuri. "The Ottoman Attitude toward Diplomacy." In Ottoman Diplomacy: Conventional or Unconventional?, edited by A. Nuri Yurdusev, 5-35. Houndmills: Palgrave, 2004.

Zhang, Yongjin. "China's Entry into International Society: Beyond the Standard of 'Civilization'." Review of International Studies 17 (1991): 3-16. 